\title{
Morphological characteristics of Phaius spp. orchids from Indonesia
}

\author{
SRI HARTATI ${ }^{1,2, \boldsymbol{v}}$, SAMANHUDI $^{1,2}$, IDA RUMIA MANURUNG $^{1,2}$, ONGKO CAHYONO $^{3}$ \\ 'Department of Agrotechnology, Faculty of Agriculture, Universitas Sebelas Maret. Jl. Ir. Sutami 36A, Surakarta 57126, Central Java, Indonesia. \\ Tel./Fax. +62-271-637457, \email: tatik_oc@yahoo.com \\ ${ }^{2}$ Center for Research and Development of Biotechnology and Biodiversity, Universitas Sebelas Maret. Jl. Ir. Sutami 36 A Surakarta 57126, Central Java, \\ Indonesia. \\ ${ }^{3}$ Department of Soil Science, Faculty of Agriculture, Universitas Sebelas Maret. Jl. Ir. Sutami 36A, Surakarta 57126, Central Java, Indonesia
}

Manuscript received: 30 December 2020. Revision accepted: 26 March 2021.

\begin{abstract}
Hartati S, Samanhudi, Manurung IR, Cahyono O. 2021. Morphological characteristics of Phaius spp. orchids from Indonesia. Biodiversitas 22: 1991-1995. Orchid is one of the ornamental plants with great economic value in various communities. Characterization and grouping of several orchid species can be used in breeding efforts to obtain hybrid with the desired traits. This study is aimed to characterize the morphological appearance of Phaius orchids and to cluster the species based on their similarity in morphological characteristics. Five species of Phaius (P. tankervilleae, P. indigoferus, P. montanus, P. amboinensis, and P. callosus) of the collection of the Bogor Botanical Garden were observed based on 30 morphological characters including the characters of stems, pseudobulbs, leaves and flowers. The data obtained were converted into binary data and computed using the Numerical Taxonomy and Multivariate Analysis System (NTSYS) Spc 2.02 program to produce dendrogram. The results show that based on the morphological characterization of the five species of Phaius spp., they have similarities from $63 \%$ to $80 \%$. Among the five Phaius species, $P$. amboinensis, $P$. tankervilleae, and $P$. montanus had $80 \%$ similarity and can be used as parents for crossing.
\end{abstract}

Keywords: Characterization, morphological, Phaius, orchids, similarity

\section{INTRODUCTION}

Orchids is a group of cosmopolitan plants that is widely distributed across the world, especially in the tropical region. Orchids are characterized with their distinctive features of unique flowering morphology with blooms that are often colorful and fragrant. They are diverse and widespread family of flowering plants. One of the genus of orchids is Phaius. This genus is characterized by the presence of bulbs and lanceolate types of leaves with pointed tips (Kurniawan et al. 2020).

There are about 20 species within the genus Phaius. which are widely distributed across India, China, Malaysia, Indonesia, Papua New Guinea, some Pacific Islands, and Australia (Simmons et al. 2018). Several species from Phaius genus are known as decorative plants which are noticeable through their color, size, shape, number of flower buds, stem length, and durable freshness (Devadas et al. 2019). Based on the stock within the Sicikeh-cikeh timberland, it is known that there are at slightest 102 species from 30 genera of orchids. The differing qualities of earthbound orchids are less than that of epiphytic orchids (Hartini, 2019).

Several studies recorded Phaius occurrence in Indonesia with each species requires specific habitat characteristics. For example, in Gunung Simpang, West Java, there were three species of Phaius, namely $P$. pauciflorus, $P$. callosus and $P$. tankervilleae. Both $P$. callosus and $P$. pauciflorus preferred to grow in shady habitats, meanwhile, $P$. tankervilleae lived in open and exposed areas with direct sunlight. Among them, $P$. pauciflorus was the most abundant in Mount Simpang (Puspitaningtyas 2005).

Taxonomical characterization is the first step for the sustainable utilization and conservation of biodiversity including for orchids. This characterization is fundamental to determine the variations in morphological features, either in the vegetative or generative organs. Viewed from utilization perspective, characterization can be used as a basis for phylogenetic studies to determine crop diversification patterns (Freudenstein et al. 2015). Morphological characterization in orchids is also very important in breeding efforts for conservation and agribusiness purposes (Kasutjianingati and Firgiyanto 2018). The characterization result of 10 native Dendrobium orchids having a place to spatulata segment in Indonesia can be utilized as logical data for many requirements in cross-breeding movement, propagation, conservation of germplasm and hereditary change (Indraloka et al. 2019).

All orchid species depend on other plants and their living biological system to survive. In the period of climate alter, seriously observing work on the differences of this range is still critically required for detecting changes to this important woodland in terms of status security and utilization of its plant differing qualities. Thus providing pattern data on plant and orchid diversity information could be a fundamental step to be modified and should be prioritized by Indonesian preservation specialists (Hartini, 2019).

Several studies have investigated the morphological characteristics of orchids, including in Vanda spp. (De et al. 2015a), Phalaenopsis (Jang, 2015; Deng et al 2015), Dendrobium spp. (De et al. 2015b; Darmawati et al. 
2018; Indraloka et al. 2019), Coelogyne spp. (Hartati et al. 2019a); Phaius spp. (Devadas et al, 2019; Hartati et al. 2021). The objective of this study is to determine the similarity of five natural Phaius species based on qualitative morphological characters to select the prospective parents for crossing efforts.

\section{MATERIALS AND METHODS}

The morphological characterization of orchids was carried out at the Bogor Botanical Gardens, Research Center for Plant Conservation and Botanic Gardens, Indonesian Institute of Sciences (LIPI). The morphological characterization of orchids was carried out at the Bogor Botanical Gardens Conservation Center. The materials used were five Phaius spp. species, namely $P$. amboinensis, $P$. callosus, $P$. tankervilleae, $P$. montanus, and $P$. indigoferus which were the collection of the Bogor Botanical Garden (Figure 1).

This study used descriptive method by direct observation. The documentation and characterization of the morphology of species based on the guide from the Indonesian Ornamental Plants Research Institute (Balithi 2007).

The qualitative observation of Phaius spp. consisted of 30 characters, namely growth type, leaf shape, leaf crosssection, tip leaf shape, leaf arrangement, leaf edge shape, leaf surface texture, symmetry leaf, leaf color, type of flowering, resupinate flower's shape, dorsal and lateral sepal shape, transverse and longitudinal shapes of dorsal and petal, petal shape, sepal petal tip shape, type of callus, lip curvature, murmur in the labellum (to attract insects), cross-section of the lip, spurs, flowering position, amount of pollinia, dorsal sepal color pattern, lateral sepal color pattern, petal collar pattern, floral aroma, pseudobulb longitude section, pseudobulb cross-section shape, rooting type and pseudobulb size.

Data analysis was performed by scoring the morphological features into binary data, i.e. (1) if the morphological character was present; or (0) if the character was absent. Based on the morphological data, a similarity index was calculated to cluster the species using the Unweighted Pair Group Methods using Arithmetic averages (UPGMA) software functional SIMQUAL (Qualitative Similarity). The data obtained were also analyzed using the NTSYS-PC (Numerical Taxonomy and Multivariate Analysis System) version 2:02.

\section{RESULTS AND DISCUSSION}

\section{Morphological characterization of Phaius orchids}

The determination of morphological characters was carried out on plant parts, namely stems, flowers, leaves, roots, seeds, and fruit, which were identified and documented (Indraloka et al. 2019). Leaves on orchids have several variations from elongated round to roundedlike in general, lacked leaf bones that form a spread mesh, however parallel to the blade.

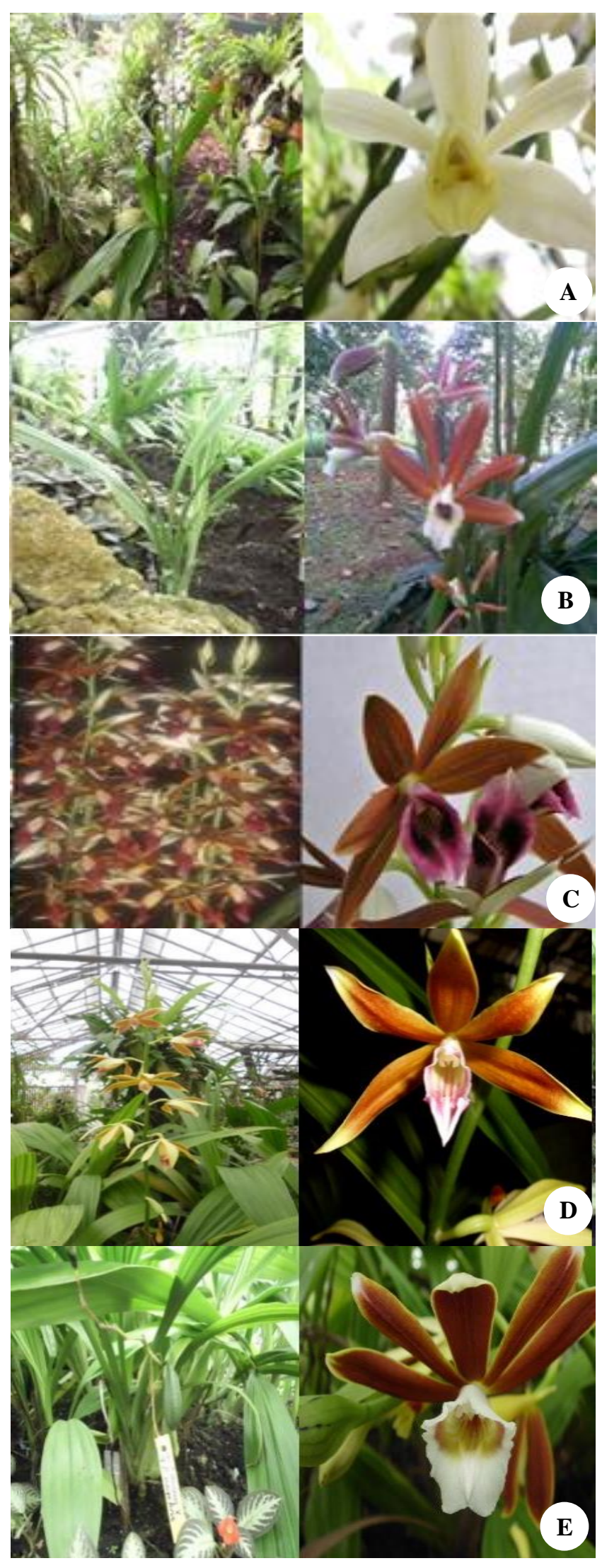

Figure 1. The Morphological of Phaius spp. from Bogor Botanical Garden, Indonesia. A. P. amboinensis (Bali); B. P. callosus (Jawa); C. P. tankervilleae (Sulawesi); D. P. montanus (Papua); E. P. indigoferus (Sulawesi) 
The leaf bones also vary from thin to thick fleshy (Lokho and Kumar 2012). The relationship between plants was determined through the leaf's anatomical characteristics (Darmawati et al. 2018). The presence of pseudobulb will reduce the loss of water content in leaves during drought by proper channeling (Tay et al. 2015).

Table 1 shows that there are similarities in many morphological characters of the five Phaius spp., including growth type, leaf shape, leaf cross-section, tip leaf shape, leaf edge shape, leaf surface texture, symmetry leaf, leaf color, flower's shape, resupinate, petal shape, sepal petal tip shape, type of callus, pseudobulb longitude shape, pseudobulb cross-section shape, root type. On the other hand, there are some differences among the five species.

For example, $P$. amboinensis has morphological differences with the other four Phaius spp. in terms of the absence of spur, flowering position, pollinia, and sepal dorsal collar pattern. Based on the observation, the shape of Phaius spp. leaves were lanceolate (elongated flat). Meanwhile, $P$. callosus has morphological differences from the other four Phaius spp. in characters of transverse and longitudinal shape of dorsal and petal, dorsal sepal collar pattern, lateral sepal color pattern, petal color pattern, floral aroma, and pseudobulb size. The ground orchid Phaius callosus (Blume) is synonymous with Limodorum callosum Blume and Phaius kuhlii Rchb.f. has a large and sturdy stature, up to $1 \mathrm{~m}$ high. The leaves are elongated, fleshy and up to $70 \mathrm{~cm}$ long. Inflorescences emerge from the tips of the stems, towering over the length of the leaves. One inflorescence supports 5-12 flowers that are reddish-brown in color. The lips are funnel-shaped, white with purple stripes on the inside. Meanwhile, $P$. tankervilleae has differences from the other four Phaius in terms of location of labellum curve, cross-section of the labellum and sepal lateral color pattern. P. montanus differs from the other four Phaius spp. in terms of lateral sepal color pattern and petal color pattern. $P$. indigoferus has differences in its carcinoma with the other four Phaius spp. in the flowering position, pollinia, dorsal collar pattern, sepal lateral color pattern and petal color pattern.

Tabel 1. Morphological characters of five Phaius spp.

\begin{tabular}{|c|c|c|c|c|c|}
\hline \multirow{2}{*}{$\begin{array}{c}\text { Character } \\
\text { morphology }\end{array}$} & \multicolumn{5}{|c|}{ Species } \\
\hline & P. amboinensis & P. callosus & P. tankervilleae & P. montanus & P. indigoferus \\
\hline Growth type & Sympodial & Sympodial & Sympodial & Sympodial & Sympodial \\
\hline Leaf shape & Lanceolate & Lanceolate & Lanceolate & Lanceolate & Lanceolate \\
\hline Leaf cross-section & Plicate & Plicate & Plicate & Plicate & Plicate \\
\hline Tip leaf shape & Acuminate & Acuminate & Acuminate & Acuminate & Acuminate \\
\hline Leaf arrangement & Convulate & Convulate & Convulate & Convulate & Rolled leaves \\
\hline Leaf edge shape & Curse & Curse & Curse & Curse & Curse \\
\hline Leaf surface texture & Glabrous & Glabrous & Glabrous & Glabrous & Glabrous \\
\hline Symmetry leaf & Symmetry & Symmetry & Symmetry & Symmetry & Symmetry \\
\hline Leaf color & Light green & Light green & Light green & Light green & Light green \\
\hline Flower's shape & Star & Star & Star & Star & Star \\
\hline Resupinate & Resupinate & Resupinate & Resupinate & Resupinate & Resupinate \\
\hline $\begin{array}{l}\text { Dorsal \& lateral sepal } \\
\text { shape }\end{array}$ & Oval & Ovoid & Oval & Oval & Oval \\
\hline $\begin{array}{l}\text { Transverse \& } \\
\text { longitudinal shape of } \\
\text { dorsal and petal }\end{array}$ & Concave & Sunken & Concave & Concave & Convex \\
\hline Petal shape & Straight & Straight & Oval & Straight & Oval \\
\hline Sepal petal tip shape & Taper & Taper & Taper & Taper & Taper \\
\hline Type of callus & Simple & Simple & Simple & Simple & Simple \\
\hline Lip curvature & At the tip & At the tip & At the middle & At the tip & At the tip \\
\hline Murmur in the labellum & Murmur & Murmur & Murmur & Murmur & Murmur \\
\hline Cross-section of lip & $\begin{array}{l}\text { Curved slightly } \\
\text { inward }\end{array}$ & Flipped out & Flat & Curved slightly inward & Flipped out \\
\hline Spur & No spur & Spur & Spur & Spur & Spur \\
\hline Flowering position & $\begin{array}{l}\text { Next to or between } \\
\text { armpits }\end{array}$ & At the base & At the base & At the base & At the top \\
\hline Amount of Pollinia & 2 & 8 & 4 & 8 & 8 \\
\hline $\begin{array}{l}\text { Dorsal sepal color } \\
\text { pattern }\end{array}$ & Equally & Edge and striped & Edge & Edge & Striped \\
\hline $\begin{array}{l}\text { Lateral sepal color } \\
\text { pattern }\end{array}$ & Equally & Edge and striped & Equally & Patterned and striped & Edge \\
\hline Petal color pattern & Equally & Pattern & Equally & Patterned and striped & Edge \\
\hline Floral aroma & No aroma & Smelling & Smelling & No aroma & No aroma \\
\hline $\begin{array}{l}\text { Pseudobulb longitude } \\
\text { section }\end{array}$ & Ovate & Ovate & Ovate & Ovate & Ovate \\
\hline $\begin{array}{l}\text { Pseudobulb cross- } \\
\text { section shape }\end{array}$ & Round & Round & Round & Round & Round \\
\hline Rooting type & Fiber & Fiber & Fiber & Fiber & Fiber \\
\hline Pseudobulb size & Large & Medium & Large & Large & Medium \\
\hline
\end{tabular}


The orchids are called androgynous plants (hermaphrodites), their pollen and pistil are contained in one flower, while the sex characteristics are monoandre (male and female genitalia were located in one place). Therefore, they are easily pollinating. Plants like orchids have structures that consist of roots, stems, leaves and flowers. The main plant characteristic can be identified from roots, stems, leaves, flowers, fruits and seeds, with a wide variety of colors and shapes. The structure mainly were petal, sepal, pollinia, column, and labellum (Castro and Singer 2019). The root types in orchids are divided into 3 , namely ground, air, and sticky, and were for attachment to the plant growing media. In terrestrial orchids, the roots have long and dense hairs which function as absorbing water and organic matter in the soil. Khairiah et al (2012) stated that orchids have rhizome roots-like tubers. Puspitaningtyas (2005) states $P$. pauciflorus and P. callosus prefer to grow in shady habitats, while $P$. tankervilleae live in open, direct sunlight, among grasses and Andam ferns (Gleichenia linearis). Phaius tankervilleae is a beautiful, highly ornamental and valuable ethnobotanical orchid. (Kanwal 2014). Several species of the genus Phaius are known as ornamental plants which can be seen from their color, size, shape, number of flower buds, stem length and long-lasting freshness (Ackerman 2012).

The dendrogram of Phaius spp. based on morphological characters is presented in Figure 2. The dendrogram shows that morphological similarity among the five orchids is between $63 \%-80 \%$. Using threshold of 0.79 , the five Phaius can be clustered into three groups, i.e., the first group consists of $P$. amboinensis, $P$. tankervilleae and $P$. montanus, the second group is $P$. callosus and the third is $P$. indigoferus. Morphological characters are used to identify and analyze the diversity of close relationships between species in orchids (Kasutjianingati and Firgiyanto 2018).

The study showed that based on qualitative characters, the genotypes of $P$. amboinensis, $P$. tankervilleae and $P$. montanus show high similarity $(80 \%)$ compared to the other genotypes (Figure 2). On the other study based on quantitative identification, Hartati et al (2021) found that other Phaius spp., $P$. amboinensis and $P$. indigoferus showed morphological similarity of $87 \%$. The results of quantitative identification, the number of flowers of 5 Phaius spp., P. indigoferus had 22 flowers, P. tankervilleae had 18 flowers, $P$. amboinensis had 15 flowers, $P$. montanus had 13 flowers and $P$. collasus had 10 flowers. The study showed length of the flower stalk was directly proportional to the number of flower buds. The longer the flower stalk the greater the number of flowers. P.indigoferus has the longest flower stalk, and therefore a greater flower number than the other species.

The other study reported that based on qualitative identification among six orchid species of Coelogyne, two species that had high similarity (i.e. 87\%) were $C$. pandurata and C. rumphi (Hartati et al. 2019a). Identification of character similarity can also be done by the molecular characteristics using ISSR (lnter Simple Sequence Repeats). Hartati (2017) showed that the genetic similarity of $C$. pandurata with $C$. rumphii was $51 \%$.
Furthermore, the crosses of $C$. pandurata and $C$. rumphii are $100 \%$ successful using selfing, crossing, and reciprocal methods (Hartati et al. 2019b). Further research to determine the molecular characteristics using RAPD (Random Amplified Polymorphic DNA) showed that analysis has successfully detected genetic variation of $\bigcirc C$. rumphii, ô $C$. pandurata, and their F1 hybrids. The orchid parents and their F1 hybrid have a similarity range of 16$100 \%$ (Hartati and Muliawati 2020).

The results of the research on the clustering of five species of Phaius spp. can be used as selection of parental candidates of crossing in order to create more potential orchids. According to Lokho and Kumar (2012), the morphological character of orchids is useful for resource management, conservation of individual species, and hybridization, cultivation and germplasm conservation as well as genetic improvement. all contradiction with other orchid genera shows limit hereditary base, but found to be consistent inside genera conjointly self-consistent. The new essential crossbreed from inborn species created can serve as perfect reference fabric for taxonomical studies and can be valuable as hereditary stock for development as terrestrial plants with great versatility sub-tropical conditions. Population improvement in the F2 era may disentangle the genetic control of different characteristics and help develop the classical hereditary outline in Phaius. Assist change can be done through markers, change breeding and hybridization with its close relatives like Calanthe, etc. (Devadas et al. 2019). De et al. (2015b) conducted research on morphological characterization of Dendrobium species to determine the morphological development of descriptors based on the International Union for the Protection of New Varieties of Plants (UPOV) guidelines and a total of 62 morphological descriptors of Dendrobium were developed.

In conclusion, based on the morphological characterization of the five species of Phaius spp., they have similarities from $63 \%$ to $80 \%$. Among the five of Phaius spp. being morphologically tested showed that $P$. amboinensis, $P$. tankervilleae, and P. montanus had $80 \%$ similarity and could be used as parents for crossing to obtain the desired hybrid.

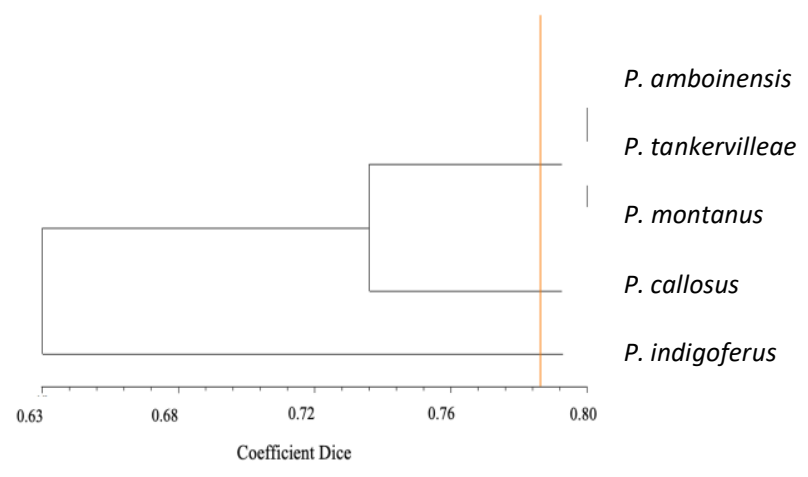

Figure 2. Dendrogram of Phaius spp. based on qualitative morphological characters 


\section{ACKNOWLEDGEMENTS}

This research was conducted with financial support from the Universitas Sebelas Maret, Surakarta, Indonesia under the research scheme of Penelitian Unggulan for fiscal year 2020 with contract number of 452/UN27.21/2020.

\section{REFERENCES}

Ackerman JD. 2012. Orchids gone wild: Discovering naturalized orchids in Hawaii. Bull Am Orchid Soc 8: 88-93.

Balithi. 2007. Panduan karakteristik tanaman hias anggrek. Pusat Penelitian dan Pengembangan Hortikultura. Departemen Pertanian Republik Indonesia. [Indonesian]

Castro JB, Singer RB. 2019. A literature review of the pollination strategies and breeding systems in Oncidiinae orchids. Acta Bot Bras 33 (4): 618-643. DOI: 10.1590/0102-33062019abb0111

Darmawati IAP, Rai IN, Dwiyanti R, Astarini IA. 2018. Analysis on relationship among Dendrobium spp Bali based on characteristics of leaves anatomy. Intl J Biosci Biotechnol. 5 (2): 111-117. DOI 10.24843/IJBB.2018.v05.i02.p03.

De LC, Rao AN, Rajeevan PK, Srivastava M, Chhetri G. 2015a Morphological characterization in Vanda species. Int J Sci Res 4 (1): 26-32. DOI: 10.36106/ijsr.

De LC, Rao AN, Rajeevan PK, Srivastava M, Chhetri G. 2015b. Morphological characterization in Dendrobium species. J Global Biosci 4 (1): 1198-1215.

Deng H, Guo Qz, Zhong JL, Yan W. 2015. A new species and a new combination of Phalaenopsis (Orchidaceae: Epidendroideae: Aeridinae): evidence from morphological and DNA analysis Phytotaxa 238 (3): 243-254. DOI: 10.11646/phytotaxa.238.3.3.

Devadas R, Pamarthi RK, Meitei AL, Pattanayak SL, Sherpa R. 2019 Morphological description of novel Phaius primary hybrid (Orchidaceae). J Exp Biol Agric Sci 7 (2): 138-147. DOI 10.18006/2019.7(2).138.147.

Freudenstein JV, Chase MW. 2015. Phylogenetic relationships in Epidendroideae (Orchidaceae), one of the great flowering plant radiations: Progressive specialization and diversification. Ann Bot 115: 665-681. DOI: 10.1093/aob/mcu253

Hartati S, Nandariyah, Yunus A, Djoar DW. 2019b. Hybridization technique of black orchid (Coelogyne pandurata Lindley) to enrich the genetic diversity and to rescue the genetic extinction. Bulgarian $\mathrm{J}$ Agric Sci 25 (4): 751-755.

Hartati S, Indrawati AS, Sulistyo TD. 2021. Morphological characterization of natural orchids Phaius spp. IOP Conf. Series:
Earth Environ Sci 637: 012091. DOI: 10.1088/1755$1315 / 637 / 1 / 012091$

Hartati S, Muliawati 2020. Genetic variation of Coelogyne pandurata, $C$ rumphii and their hybrids based on RAPD markers. Biodiversitas 21 (10): 4709-4713. DOI: 10.13057/biodiv/d211033.

Hartati S, Muliawati ES, Pardono, Cahyono O, Yulianto P. 2019a. Morphological characterization of Coelogyne spp for germplasm conservation of orchids. Rev Ceres Vicosa 66 (4): 265-270. DOI: 10.1590/0034-737x201966040004.

Hartati S. 2017. Study of genetic diversity on six species of Indonesian Coelogyne spp. based on ISSR markers. Pak J Biol Sci 20: 577-583. DOI: $10.3923 /$ pjbs.2017.577.583.

Hartini S. 2019. Orchids Diversity in the Sicikeh-Cikeh Forest, North Sumatra, Indonesia. Biodiversitas 20 (4): 1087-1096. DOI: 10.13057/biodiv/d200421.

Indraloka AB, Dewanti P, Restanto DP. 2019. Morphological characteristics and pollinia observation of 10 Indonesia native Dendrobium orchids. Biovalentia Biol Res J 5 (2): 38-45. DOI: 10.24233/BIOV.5.2.2019.140

Jang S. 2015. Functional characterization of PhapLEAFY, aFLORICAULA/LEAFY Ortholog in Phalaenopsis aphrodite. Plant Cell Physiol 56 (11): 2234-2247. DOI: 10.1093/pcp/pcv130.

Kanwal KS 2014. Conservation of Phaius tankervilleae a valuable orchid of Arunachal Pradesh, India. Indian Forester 140 (12): 1263-1264.

Kasutjianingati K, Firgiyanto R. 2018. Characterization of morphology from orchid Vanda sp. as a genetic information source for preservation and agribusiness of orchids in Indonesia. IOP Conf Ser Earth Environ Sci 207: 012006. DOI: 10.1088/17551315/207/1/012006

Khairiah, Chairuman N, Fadly M. 2012. Species of orchids in North Sumatra. Proceedings of the National Orchid Seminar 77-85.

Kurniawan FY, Putri F, Suyoko A, Masyhuri H, Sulistianingrum MP,Semiarti E. 2020. The diversity of wild orchids in the southern slope of Mount Merapi, Yogyakarta, Indonesia, eight years after the 2010 eruption. Biodiversitas 21 (9): 4457-4465. DOI: 10.13057/biodiv/d210964.

Lokho A, Kumar Y. 2012. Reproductive phenology and morphological analysis of Indian Dendrobium Sw. (Orchidaceae) from the northeast region. Intl J Sci Res Pub 2 (9): 1-14.

Puspitaningtyas DM. 2005. Study on orchid diversity in Gunung Simpang nature reserve, West Java. Biodiversitas 6 (5): 103-107. DOI: 10.13057/biodiv/d060207. [Indonesian]

Simmons L, Mathieson MT, Lamont, RW and Shapcott A. 2018. Genetic diversity of endangered orchid Phaius australis across a fragmented Australian landscape. Conserv Genet 19 (2): 451-465. DOI: 10.1007/s10592-017-1022-y.

Tay S, He J, Yam TW. 2015. Photosynthetic light utilization efficiency, water relations and leaf growth of $\mathrm{C} 3$ and CAM tropical orchids under natural conditions. Am J Plant Sci 6: 2949-2959. DOI: 10.4236/ajps.2015.618290. 